園学雑. (J. Japan. Soc. Hort. Sci.) 58(3)：609-618. 1989.

\title{
トウガラシ属の種間雑種にお活る座止発現及び 座止発現遺伝子の地理的分布
}

\author{
矢澤 進・佐藤隆德*・並木隆和 \\ 京都府立大学農学部 606 京都市左京区下鴨
}

\begin{abstract}
Interspecific Hybrid Dwarfism and Geographical Distribution of the Dwarfness Gene in Capsicum

Susumu YAZAwA, Takanori SATO* and Takakazu NAMIKI
Faculty of Agriculture, Kyoto Prefectural University, Kyoto 606
\end{abstract}

\section{Summary}

Some cultivars of Capsicum annuum show dwarfness in their interspecific hybrids with C. chinense 'No. 3341'. The dwarfness is represented by the termination of leaf differentiation after development of several leaves in both main and lateral shoots. The dwarf plants generally maintain their growth characteristics for two years.

The top/root ratio of the dwarf plants was smaller than in normal plants. Root growth of dwarf plants increased nearly to normal by grafting of normal plants on them.

Dwarfness was shown to be controlled by two complemantary dominant genes, one of which is homozygous in 'No. 3341'. Many of the old Japanese cultivars, and the local Korean and Chinese cultivars, had another gene and developed dwarfness in hybrids with 'No. 3341'. All cultivars collected from other Asian areas, the Subcontinent of India, and North and South America did not possess the dwarf gene complementary to the gene of 'No. 3341', except for one cultivar from Guatemala.

There are two theories for the route of pepper introduction to Japan; one by Portuguese and another via Korea. The present genetical studies strongly suggest that some cultivars had been introduced from Korea to Japan.

\section{緒言}

トウガラシの原産地は, 新大陸である.メキシコの BC 7000 年頃の Tehuacán 遺跡から Capsicum annuum L. と思われる種子が, BC 2500 年頃のペルーのChicama 峡谷の遺跡から Capsicum baccatum L. の種子がそれ ぞれ出土し，当時すでに新大陸の人々により利用されて いたといわれている(2)、ヨーロッパへは，15 世紀末に コロンブスにより新大陸から持ちこまれたとされている (11)。我が国には，16 世紀に渡来し，江戸時代には香辛 料や観賞用として利用されていた(14).

トウガラシ属の種間の交雑率や $\mathrm{F}_{1}$ における花粉稔性 調查 $(9,12,30)$ 及び染色体の核型分析の結果 $(17,19)$ か ら，種の類縁関係の検討が行われている．また，最近

1988 年 6 月 30 日 受理

* 現在 : 農林水産省野菜・茶業試験場 514-23 三重 県安芸郡
Egawa と Tanaka $(6,7,8)$ は, 種間交雑における染色 体の対合性などから種の成立過程に言及し，トウガラシ の種の分化には染色体の相互転座が重要な役割を演じて いることを指摘している.

広瀬ら(12)は, ‘タバスュ'(Capsicum frutescens $\mathrm{L}$.) に‘ししとう’（C. annuum）を交雑して得られた $\mathrm{F}_{1} か ゙ ，$ 発芽後数節を分化して，生育を停止することを認めてい る.ここでは，このような生育初期の生育停止による矮 化現象を “座止” と呼ぶ． $F_{1}$ が生育を停止したり，黄 化あるいは觉そを生じて枯死する例は，トゥガラシ（4, 12,15）の他にカボチ+(35)，イネ(18)，コムギ(10，22， 24), オオムギ(21)，インダン $(5,20)$ 及びササゲ(3) な ど数多くの作物で知られている. 特にコムギやオオムギ では, 品種間交雑における学にの発生や幼苗致死の遗伝 分析とその遺伝子を持つ品種の地理的分布が明らかにさ れている(21, 25〜29, 36). 
本実験では, トウガラシ属の種間雑種にみられる座止 個体の形態的特性, 座止発現の遺伝様式及び座止遺伝子 を持つ品種の地理的分布について検討した。

\section{材料及び方法}

予備実験の結果 (31) から，C. annuum の品種 “伏見 甘長’及び ‘ししと と’ Capsicum chinense Jacq. 'No. 3341'（第 1 図）を交雑すると $F_{1}$ が座止すること が認められている. C. chinense 'No. 3341' は, 1973 年京都大学ラテン・アメリカ科学調査隊が, ボリビアの Cobija で採集したものである(30).

'No. 3341' と C. annuum の品種との種間交雑を行 う場合には，すべて ‘No. 3341’を花粉親とした. $C$. annuum を花粉親とした場合は, 交雑が不可能であっ た.

座止個体の茎頂部及び茎の断面の観察は, 生体切片作 製用ミクロトームで切片を作製し，検鏡した。

巫止個体の根の発育状態を調査するために, 水耕栽培 を行った. 供試材料は, 座止を発現する種間雑種 “伏見 甘長 $\times$ No. 3341'， ‘ししと5’，“伏見甘長 $\times$ No. 3341’を 穂木として ‘ししとう’を台木とした接ぎ木個体ならび に“ししとう’に‘ししと5’を接ぎ木した共台のものと した. ‘伏見甘長 $\times$ No. 3341' 及び台木用の ‘ししとう’ は，1980年 2 月 21 日に播種した. 自根で生育させた ‘ししとう’及び接ぎ穂品種は 3 月 3 日に播種した. 台木 用の ‘ししとう’を 3 月 13 日に鉢上げし，4月 11 日に 插し接ぎ法により接ぎ木を行った，5月７日にれき耕用 園試処方第一例培養液の多量要素 50\%, 微量要素 100\% の培養液(以下, 園試処方 $50 \%$ 培養液と省略) の入った $45 l$ のプラスチックペールに 1 個体を定植し, 小型エア 一・ポンプで連続通気を行った。 供試個体数は, 各区 4 個体とした。ただし，“伏見甘長 $\times$ No. 3341’は， 5 月 9 日に 2 個体, 5 月 15 日 2 個体を水道水の入った $45 l$ プ ラスチックペールに定植し，徐々に園試処方 $50 \%$ 培養 液を加光，5月 28 日に培養液を園試処方 $50 \%$ 培養液と し，栽培した。このような複雑な培養液管理を行ったの は, 培養液に含まれる NaFe EDTA が移植苗に対し, 著しい生育障害を引き起こすことによるためである(32 〜34).

各区とも水耕栽培を行った後, 43 日目に茎葉重及び根 重を測定した。 ただし，“伏見甘長 $\times$ No. 3341’は培養 液を園試処方 $50 \%$ 培養液とした 5 月 28 日から 43 日目 に茎葉重及び根重の調査を行った。

つぎに，座止発現の遺伝様式を調べるために，以下の よ5な交雑組合せを設け, 交雑当代の座止発現個体と正 常に発育する個体数の分離比を求めた.

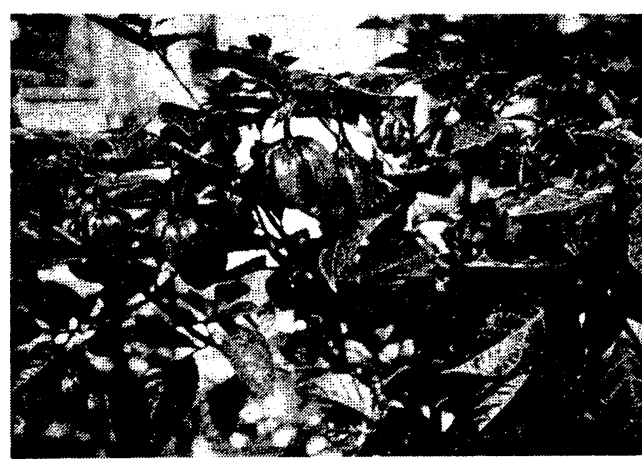

第 1 図 C. chinense 'No. 3341' の結実の状態

交雑組合せ： ‘ししと5 $\times$ No. 3341 ’, ‘伏見甘長 $\times$ No. 3341', ‘カリフォルニア・ワンダー $\times$ No. 3341 ’, ‘紫 $\times$ No. 3341', ‘ししと5×カリフォルニア・ワンダー’ $\times$ 'No. 3341', ‘紫 $\times$ No. 3341'x ‘ししと5’, ‘紫 $\times$ No. 3341 ’ ‘カリフォルニア・ワンダー’, ‘カリフォルニア ・ワンダー $\times$ No. 3341 ’ 'No. 3341’, ‘紫 $\times$ No. 3341’ ×'No. 3341’， ‘ししと5 $\times$ 伏見甘長’ X'No. 3341'およ び ‘伏見甘長 $\times$ No. 3341 ’ の自家授粉.

‘乙しと5’ 及び ‘伏見甘長' に 'No. 3341' を交雑し た場合， $F_{1}$ に座止が発現するために，後述するような まれな場合を除き $\mathrm{F}_{1}$ 種子を得ることは不可能である. そのために， $F_{1}$ に座止を発現しない品種間あるいは種 間雑種を育成し，それらと'ししとう’, ‘カリフォルニ ア・ワンダー’あるいは ‘No. 3341’を交雑した。

それぞれの交雑組合せにおける，座止発現個体数と正 常に生育する個体数を調べるために, “伏見甘長 $\times$ No. 3341 を除くすべての交雑種子を 1980 年 6 月 25 日播種 し，7月25日に網目状プラスチックバット（32×44×16 $\mathrm{cm})$ に定植して 8 月 30 日に生育調査を行った。“伏見 甘長 $\times$ No. $3341^{\prime}$ については, 1980 年 2 月 21 日に播種 し，播種後 2 年 6 か月を経過した 1982 年 8 月に座止 個 体の一つの芽が伸長し, 自家授粉による種子が得ら れた。これらの種子を 1982 年 9 月 30 日に播種し, 12 月 25 日に生育調査を行った。 ‘伏見甘長 $\times$ No. 3341’ の長 期栽培個体に，なぜ開花，結実枝が発生したのかは不明 である.

つぎに, 'No. 3341’を花粉親とし, 我が国の 31 品種 を含むアジア，インド亜大陸及びアメリカ大陸などの諸 地域で収集あるいは入手した C. annuum の 97 品種と 交雑を行い, 各 $F_{1}$ の座止の発現及び生育状態を調査し た. 各品種の産地は, 第 1 表に示した. C. annuum の 品種の選択にあたっては, 我が国の品種を除きできる限 り各地の在来品種であることに留意した。なお，熱帯地 
第 1 表 C. annuum の供試品種及び導入国

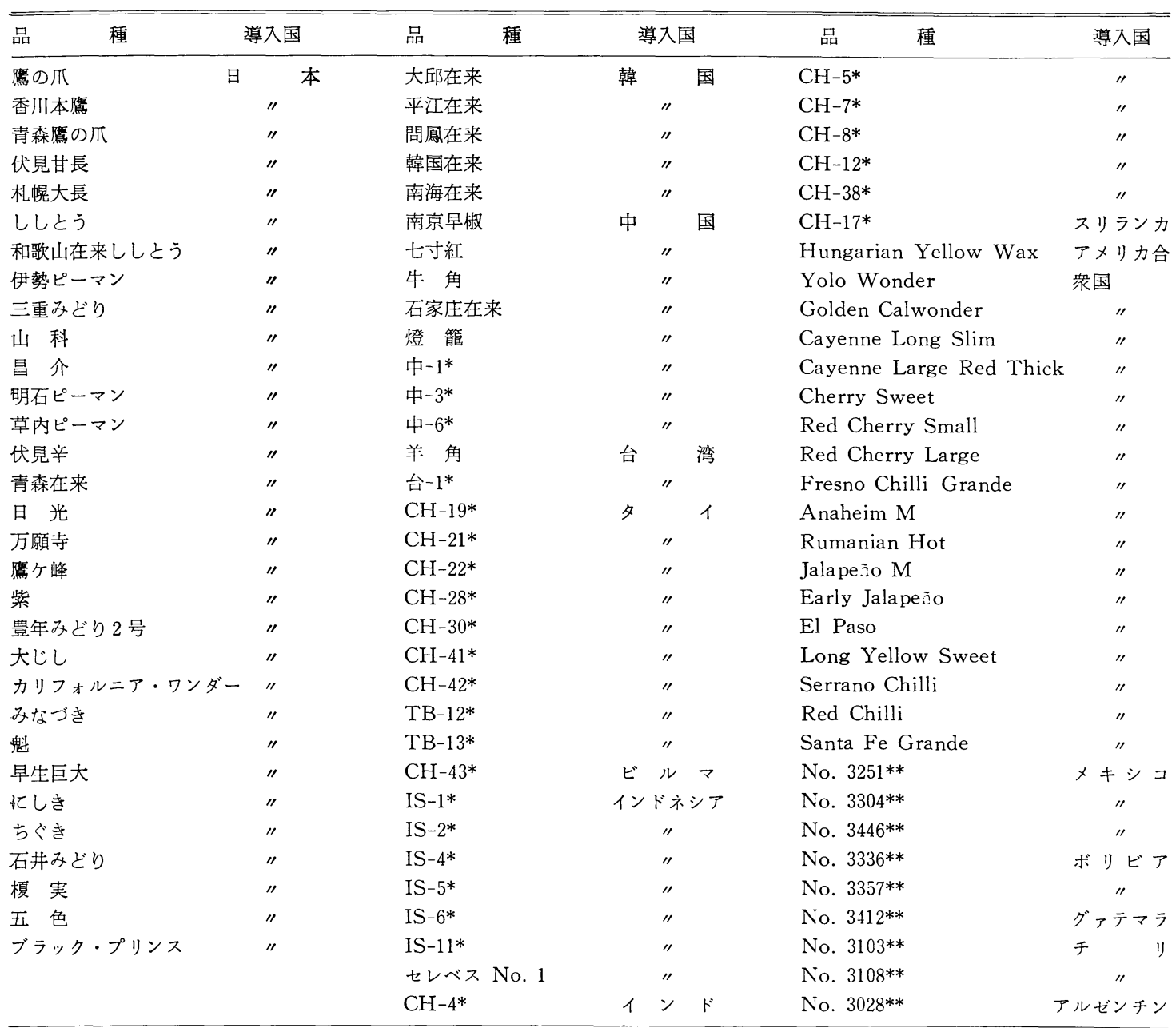

* 京都府立大学・農学部・蔬菜園芸学研究室導入番号

** 京都大学・農学部・植物生殖質研究施設導入番号

方では，正式な品種名がない場合が多いため，それぞれ の導入機関が与えた導入番号を用いた。実験は，1977年 から 1982 年にかけて行った. ‘No. 3341' と交雑するた めの品種は, ガラス室あるいはファイロンハウス内で, 7 号プラスチックポットで栽培した。供試個体数は各品 種 3 個体を基本とした。'No. 3341' との交雑は，すべ てつぼみ授粉とし，授粉後袋かけを行った． $F_{1}$ 種子の 播種日及び生育調査日は, それぞれの結果の表の欄外に 示した、いずれの実験とも $\mathrm{F}_{1}$ の生育調查日は， $\mathrm{F}_{1}$ 種 子と同じ日に播種した ‘ししとう’が $12 \sim 14$ 枚の本葉を 展開した時期とした。 1980 年 4 月 19 日に播種した $\mathrm{F}_{1}$ は, 幼苗を 4 号ポリポットに 1 個体を，その他の播種期 のものは $32 \times 44 \times 16 \mathrm{~cm}$ の網目状プラスチックバット 1
個につき 45 個体を移植した。調查個体数は，それぞれ の $\mathrm{F}_{1}$ にり 15 個体としたが，一部の $\mathrm{F}_{1}$ で 15 個体に 満たない場合があった．冬期は, ファイロンハウスをビ ニールで内張りを行い，最低気温が $18^{\circ} \mathrm{C}$ 以上となるよ らに加温して栽培した。

\section{結果及び考察}

座止個体の頂芽の外部形態を第 2-1 図に示した. 茎 が頂端部で急に細くなり, 新葉の展開が認められず, 生 育が停止した。座止個体の茎頂部の縦断切片をみると, 生長点は扁平で, 生長点近傍に一般涊められる小さい 細胞が少なく, 茎頂部における細胞分裂の頻度は低いむ のと思われる(第 $2-2$ 図). 座止個体の茎の横断切片を みると, 維管束の乱れなどの茎の形態上の異常は認めら 


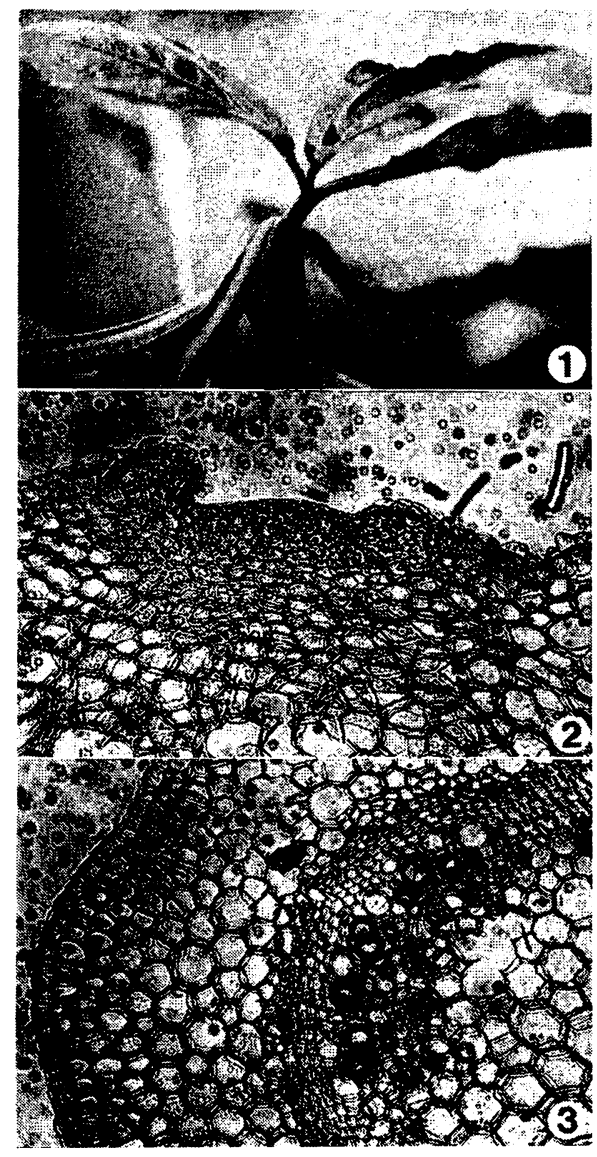

第 2 図座止個体の頂芽の外部形態(1), 茎頂部の䋛断面(2)及 び茎の横断面(3)

1：'伏見甘長 $\times$ Na. 3341', 2：'ししとう $\times$ No. 3341', 3: ‘ししとう $\times$ No. 3341'

れなかった（第 $2-3$ 図）。

座止を発現した個体は，ごくまれな場合を除き，長期 間( 2 年以上)栽培を続けても茎が正常に伸長せず，分枝 した茎も数節を分化して伸長を停止してしま5。第 3 図 は ‘ししと5 $\times$ No. 3341 ’ の播種後 1 年 6 か月を経過し たものであるが，正常な茎の伸長は認められない．

雨宮と明峯は, イネの $F_{1}$ 雑種の生育不全の詳細な生 理, 生化学的な研究結果か ら, $F_{1}$ の生育不全は植物木 ルモンなどの特定の物質の不足によるものではなく，根 端の呼吸あるいはそれに関連ある代謝系における生理機 能の障害によるものと推測している(1)。トゥガラシの 座止発現の生理的な機構は, 現在不明である.

第 2 表に座止を発現する ‘伏見甘長 $\times$ No. 3341 ’， ‘ しとう’, ‘ししとう’ の共台及び “伏見甘長 $\times$ No. 3341' を台木として‘ししとう’を接ぎ木した場合の茎葉, 根

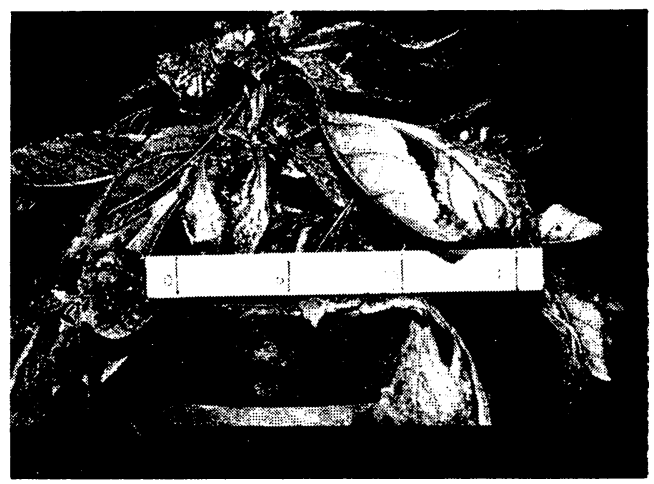

第 3 図 ‘ししとう $\times$ No. 3341 ’ の播種後 1 年 6 か月を経過 した個体

スケールの単位は $\mathrm{cm}$

の生体重と乾物重及び茎葉重/根重（TR 率）を示した. 座止を発現する ‘伏見甘長 $\times$ No. 3341 ’ の自根区の茎葉 の生体重は, ‘ししとう’自根区に比べて著しく低く0.15 倍であった。根の生体重は, ‘伏見甘長 $\times$ No. 3341’ 自 根区は，“ししとう’ 自根区の 0.50 倍であった. TR 率 は，“伏見甘長 $\times$ No. 3341 ’自根区が0.8, ‘ししと弓’自 根区が 2.7 となり著しい違いが認められた。ししとう’ ‘伏見甘長 $\times$ No. 3341 ’接ぎ木区と ‘ししとう’の共台区 では，茎葉及び根の生体重は ‘ししと 5 ’ 伏見甘長 $\times$ No. 3341' 接ぎ木区は 'ししと弓’ 共台区の 0.60 倍, 0.57 倍であった。 TR 率は, ‘ししとう’/“伏見甘長 $\times$ No. 3341’ 接ぎ木区で 3.0 , ‘ししと5’共台区で 2.9 と ほとんど違いが認められなかった，茎葉および根の乾物 重についても生体重と同じような結果が得られた。

以上の接ぎ木実験の結果から, 座止発現個体の茎葉は 正常に生育する個体の茎葉に比べて著しく小さいが，根 は茎葉汪ど生育の抑制が認められないことが明らかとな った。

トウガラシの場合とは異なり、イネ(1) やオオムギ （23）などの $\mathrm{F}_{1}$ 雑種にみられる生育不全は，根の著し い生育抑制に原因するとされている. トウガラシの座止 発現個体の根に，茎葉ほぞの生育抑制がみられない原因 については，詳細に検討する必要がある，器官の違いに より生育の抑制程度が異なることは形態形成の面からも 興味ある問題である。

$\mathrm{F}_{1}$ ならびに三系交雑における，正常及び座止発現個 体の数と分離比を第 3 表に示した. ‘ししと $5 \times$ No. 3341’，“伏見甘長 $\times$ No. 3341’ではすべての個体が座止 を発現し，‘カリフォルニア・ワンダー ×No. 3341’、“紫 $\times$ No. 3341 ’では，すべて正常に生育した。 なお，第 3 表に結果を示さなかったが，品種間交雑の $F_{1}$ でもすべ 
第 2 表 座止及び正常個体の茎葉ならびに根の生育

\begin{tabular}{|c|c|c|c|c|c|c|c|}
\hline \multirow{2}{*}{ 処 } & \multirow{2}{*}{ 区 } & \multicolumn{2}{|c|}{ 生体重 (g) } & \multirow{2}{*}{$\mathrm{T} / \mathrm{R}$ 率 } & \multicolumn{2}{|c|}{ 乾物重 (g) } & \multirow{2}{*}{$\mathrm{T} / \mathrm{R}$ 率 } \\
\hline & & 茎葉 $(T)$ & 根 $(R)$ & & 荃葉 $(\mathrm{T})$ & 根 $(R)$ & \\
\hline ししとう自根区 & & 370 & 139 & 2.7 & 46 & 10 & 4.6 \\
\hline （伏見甘長 $\times$ No. & 3341）自根区 & 54 & 70 & 0.8 & 11 & 5 & 2.2 \\
\hline ししとう共台区 & & 451 & 157 & 2.9 & 51 & 11 & 4.6 \\
\hline ししとう/伏見甘 & 寸長 $\times$ No. 3341）接ぎ木区 & 269 & 90 & 3.0 & 39 & 6 & 6.5 \\
\hline
\end{tabular}

第 3 表 三系雑種及び座止個体の $\mathrm{F}_{2}$ 世代における正常及び座止個体の分離

\begin{tabular}{|c|c|c|c|c|c|}
\hline \multirow{2}{*}{ 交雑組合せ* } & \multicolumn{3}{|c|}{ 調査個体数 } & \multirow{2}{*}{$\chi^{2}$} & \multirow{2}{*}{$\mathrm{P}$} \\
\hline & 正常 & 座止 & 合計 & & \\
\hline (ししとう×カリフォルニア・ワンダー)×No. 3341 & 25 & 28 & 53 & $\begin{array}{r}(1: 1) \\
0.170\end{array}$ & $>0.5$ \\
\hline （紫 $\times$ No. 3311) ×ししとう & 33 & 28 & 61 & 0.410 & $>0.5$ \\
\hline (紫 $\times$ No. 3341)×カリフォルニア・ワンダー & 49 & 0 & 49 & & \\
\hline (カリフォルニア・ワンダー×No. 3341) × カリフォルニア・ワンダー & 67 & 0 & 67 & & \\
\hline (紫 $\times$ No. 3341$) \times$ No. 3341 & 24 & 0 & 24 & & \\
\hline (ししとう×伏見甘長) $\times$ No. 3341 & 0 & 53 & 53 & & \\
\hline （伏見甘長 $\times$ No. $3341 ） F_{2}$ & 65 & 88 & 153 & $\begin{array}{l}(7: 9) \\
0.0999\end{array}$ & $>0.7$ \\
\hline
\end{tabular}

* ‘ししとう×No. 3341’, ‘伏見甘長 $\times$ No. 3341’ はすべて座止を発現し, ‘カリフォルニア・ワンダー×No. 3341’, ‘紫 $\times$ No. 3341 ’ はすべて正常に生育する (第 4 表参照).

ての個体が正常に生育した．座止を発現しない交雑組合 せである ‘ししと5×カリフォルニア・ワンダーに No. 3341'を，“紫×No. 3341'に‘ししとう’を交雑する と, 正常個体と座止個体とが $1: 1$ の割合に分離した. また，“紫 $\times$ No. 3341’， ‘カリフォルニア・ワンダー $\times$ No. 3341'に“カリフォルニア・ワンダー’を交雑する と,すべての個体が正常に生育した. さらに，“柴 $\times$ No. 3341’ に ‘No. 3341’を交雑してもすべての個体が正常 に生育した. 一方， ‘ししとう×伏見甘長’に ‘No. 3341' を交雑するとすべての個体が座止を発現した. ‘伏見甘長 $\times$ No. 3341' は普通, 座止を発現し正常に発育すること はない，しかし，長期間栽培を続けるとごくまれに側枝 が正常に発育し，結実する (第 4 図).このような側枝 から得られた ‘伏見甘長 $\times$ No. $3341 ’$ の $\mathrm{F}_{2}$ における正 常及び座止発現個体の分離比は， $7: 9$ となった。 この 分離比の結果から，種間交雑に伴 5 座止発現は，異なる 染色体上にある 2 対の優性補足遺伝子が関与しているこ とが明らかとなった。

以上，三系交雑の結果などから，それぞれの品種の座 止遺伝子構成はつぎのようになる.

'No. 3341': AAbb. ‘ししと5'及び ‘伏見甘長' : a aBB， ‘カリフォルニア・ワンダー’ 及び “紫’ : aabb.

交雑に伴 5生育不全は, イネ $(1,18)$, コムギ(24) 及 びオオムギ(21) などでは，ここで述べたトウガラシの

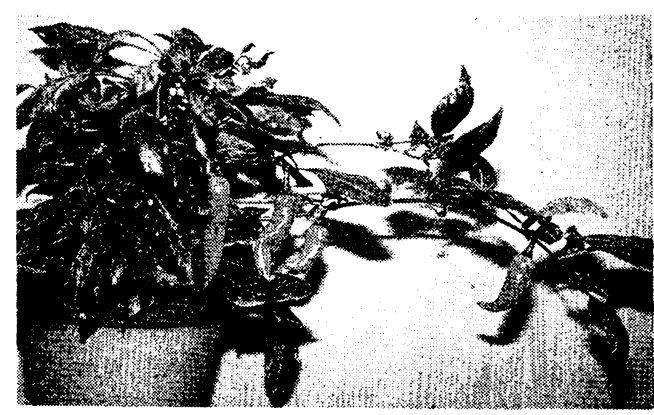

第 4 図 ‘伏見甘長 $\times$ No. 3341 ’ の結実の状態 播種後 2 年 6 か月を経過

場合と同様， 2 対の優性補足遺伝子が関与していること が認められている。このような生育不全を誘起する補足 遺伝子は普通，単独で形質を発現しないままで作物集団 内に保有されているため, その存在は交雑実験の結果か ら初めて明らかになるものである。 また，このような遺 伝子は，直接的な人為選抜の対象とならないことから， 品種の類縁関係や品種の分布過程を知る一つの重要なも のであると考えられる。

つぎに, 我が国の C. annuum の栽培品種と“No. 3341 ’ との $F_{1}$ における幼苗期の生育調查の結果を第 4 表に示した。

座止個体の草たけをみると, 最も低いものは“昌介” 
第 4 表 我が国の栽培品種と 'No. 3341’ との $F_{1}$ の生育調査

\begin{tabular}{|c|c|c|c|c|c|}
\hline $\begin{array}{c}\mathrm{F}_{1} \\
\text { (雑種第一代) }\end{array}$ & & $\begin{array}{l}\text { 草たけ } \\
(\mathrm{cm})\end{array}$ & $\begin{array}{l}\text { 本 葉 } \\
\text { 展開数 }\end{array}$ & $\begin{array}{c}\text { 座止個体 } \\
\text { 発 琴 率 } \\
(\%)\end{array}$ & $\begin{array}{l}\text { 播種及び } \\
\text { 調 査 }\end{array}$ \\
\hline 鷹の爪 & $\times$ No. 3341 & $3.0 \pm 0.7$ & $4.0 \pm 0.9$ & 100 & 1 \\
\hline 香川本鷹 & $" \prime$ & $2.2 \pm 0.2$ & $1.5 \pm 0.3$ & 100 & 1 \\
\hline 八 房 & $x$ & $2.6 \pm 0.4$ & $4.8 \pm 2.2$ & 100 & 1 \\
\hline 青森鷹の爪 & " & $10.4 \pm 1.4$ & $6.6 \pm 0.7$ & 100 & 9 \\
\hline 伏見甘長 & $\times$ & $8.9 \pm 1.7$ & $11.1 \pm 1.8$ & 100 & 1 \\
\hline 札幌大長 & " & $2.5 \pm 0.3$ & $1.9 \pm 0.3$ & 100 & 1 \\
\hline 状見辛 & " & $12.5 \pm 0.9$ & $10.7 \pm 0.7$ & 0 & 1 \\
\hline 青森在来 & " & $16.7 \pm 2.4$ & $10.8 \pm 1.1$ & 0 & 2 \\
\hline 日 光 & " & $18.5 \pm 1.8$ & $13.8 \pm 0.6$ & 0 & 1 \\
\hline 万願寺 & " & $19.5 \pm 1.7$ & $13.1 \pm 0.6$ & 0 & 1 \\
\hline 踓ケ峰 & " & $13.0 \pm 0.2$ & $8.6 \pm 0.9$ & 0 & 3 \\
\hline ししとう & $x$ & $2.5 \pm 0.3$ & $6.0 \pm 0.8$ & 100 & 1 \\
\hline 和歌山在来ししとう & " & $4.5 \pm 0.7$ & $4.8 \pm 0.8$ & 100 & 3 \\
\hline 伊勢ピーマン & $x$ & $2.5 \pm 0.3$ & $2.5 \pm 0.6$ & 100 & 1 \\
\hline 三重みどり & $x$ & $2.5 \pm 0.5$ & $2.0 \pm 0.0$ & 100 & 1 \\
\hline 山 科 & " & $5.1 \pm 0.6$ & $5.0 \pm 0.5$ & 100 & 3 \\
\hline 昌 介 & " & $1.7 \pm 0.2$ & $3.6 \pm 0.3$ & 100 & 2 \\
\hline 明石ピーマン & " & $3.1 \pm 0.5$ & $2.5 \pm 0.4$ & 100 & 1 \\
\hline 草内ピーマン & " & $8.7 \pm 2.2$ & $6.2 \pm 1.1$ & 100 & 2 \\
\hline 豊年みどり 2 号 & " & $25.0 \pm 1.7$ & $11.1 \pm 0.6$ & 0 & 9 \\
\hline 紫 & $x$ & $14.4 \pm 0.9$ & $14.6 \pm 0.9$ & 0 & 1 \\
\hline 大じし & " & $16.2 \pm 2.2$ & $12.0 \pm 0.8$ & 0 & 1 \\
\hline カリフォルニア・ワンダー & $x$ & $13.3 \pm 3.1$ & $12.9 \pm 1.0$ & 0 & 1 \\
\hline みなづき & $x$ & $15.2 \pm 3.0$ & $12.8 \pm 0.8$ & 0 & 1 \\
\hline 魁 & $x$ & $15.6 \pm 1.8$ & $11.4 \pm 0.5$ & 0 & 1 \\
\hline 早生巨大 & $x$ & $17.0 \pm 1.3$ & $13.3 \pm 0.9$ & 0 & 1 \\
\hline そしき & " & $18.6 \pm 1.2$ & $12.9 \pm 0.4$ & 0 & 1 \\
\hline ちぐさ & " & $20.4 \pm 1.4$ & $12.3 \pm 0.7$ & 0 & 1 \\
\hline 石井みどり & " & $21.9 \pm 1.9$ & $11.7 \pm 1.0$ & 0 & 2 \\
\hline 五 色 & " & $6.6 \pm$ I. 3 & $9.0 \pm 1.4$ & 0 & 1 \\
\hline 榎 実 & " & $16.7 \pm 0.9$ & $13.1 \pm 0.3$ & 0 & 1 \\
\hline 旭 光 & " & $16.0 \pm 2.7$ & $10.2 \pm 0.9$ & 0 & 8 \\
\hline ブラック・プリンス & $x$ & $13.8 \pm 0.9$ & $13.6 \pm 0.4$ & 0 & 1 \\
\hline
\end{tabular}

草たけ及び本葉展開数の数值は， $\bar{x} \pm(0.05) \mathrm{SE}$ として表わされている.

${ }^{z}$ 座止個体については, 本葉展開数と分化節数とは同じ値になる。

$\mathrm{y}$ 播種及び調查日。

$1: 1980$ 年 4 月 9 日播種, 6 月 17 日調查, $6: 1980$ 年 12 月 5 日, 1981 年 3 月 19 日

$2: 1980$ 年 9 月 10 日, 11月11日 $7: 1980$ 年12月27日, 1981年 4 月 7 日

$3: 1980$ 年 9 月 26 日, 12 月 10 日 $8: 1982$ 年 4 月 27 日, 7 月 19,20 日

$4: 1980$ 年 10 月 6 日, 1981 年 1 月 4 日 $9: 1982$ 年 8 月 4 日, 9 月 29 日

$5: 1980$ 年11月 8 日, 1981年 3 月 4 日 $10: 1982$ 年 9 月 30 日, 12 月 25 日

との $F_{1}$ の $1.7 \mathrm{~cm}$, 最も高いものは, ‘青森鷹の爪’の $10.4 \mathrm{~cm}$ であった，展開葉までの分化節数は, 最も少な いものは ‘香川本鷹” との $F_{1}$ の 1.5 , 最も多いものは “伏見甘長’との $F_{1}$ の11.1であった. $F_{1}$ の座止発現率 は, 100\%か $0 \%$ であり, 座止個体と正常に発育する個 体が混在することはなかった，第 5 図に，我が国の代表 的な品種と No. $3341^{\prime}$ との $\mathrm{F}_{1}$ の, 播種後ほぼ 3 か月 めの生育状態を示した。
$\mathrm{F}_{1}$ に座止を発現する品種は, ‘䳡の爪’, “八房”, ‘伏見 甘長”, ‘山科”, “札幌大長”, ‘ししとう’, ‘伊勢ピーマン など古くから我が国で栽培されている青果用あるいは乾 果用品種であった。 また, 座止遺伝子（B）を持つ品種 が, 品種成立の過程で関与したとされている品種群にも 座止遺伝子を持つものがあった。 たと党ば，“伊勢ピー マン’が関与した ‘三重みどり’, ‘ししとう’が関与した “草内ピーマン’あるいは‘三重みどり’が関与した‘昌介’ 


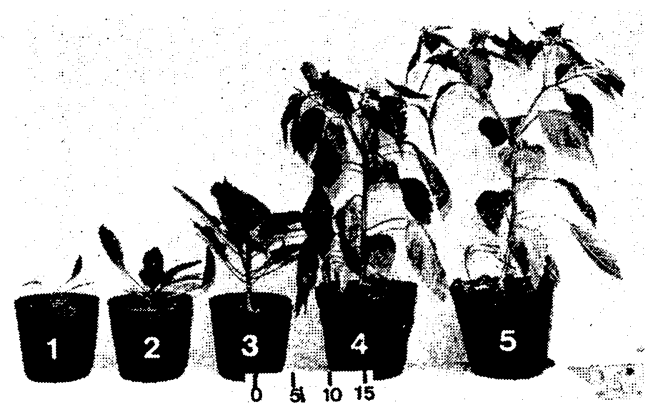

第 5 図 我汃国の代表品種と 'No. 3341' との $F_{1}$ の生育状 態

1: ‘䳡の爪 $\times$ No. 3341', 2 : ‘ししとう $\times$ No. 3341’, 3 : ‘伏見甘長 $\times$ No. 3341 ', 4 ：‘カリフォルニア・ワンダー $\times$ No. 3341 ’, 5 : ‘榎実 $\times$ No. 3341 '( 4 月 9 日播種 7 月 12 日撮影, スケールの単位は $\mathrm{cm}$ )
及び ‘明石ピーマン’などに座止遺伝子 (B)が存在した。

一方, 我が国の在来品種ではない'カリフォルニア・ ワンダー’, ‘なづき’, ‘魁’, ‘にしき’, ‘ちぐさ’など のベル型の大果あるいは中じし型品種群及び鑑賞用品種 群には座止遺伝子（B）が存在しなかった。

我が国以外のアジア及びインド覀大陸の品種と ‘No. 3341 ' との $\mathrm{F}_{1}$ の生育調査の結果を第 5 表に示した. 6 品種が $F_{1}$ で座止を発現した. 座止を発現した品種は, 韓国の ‘大邱在来”, ‘平江在来’ 及び ‘問鳳在来”之, 中 国の品種 ‘南京早椒’, ‘七寸紅’ 及び ‘中-3’ であった, 台湾, タイ, ビルマ, インドネシア，インド，スリラン カの品種には座止遺伝子（B）を持つ品種は，まったく

第 5 表 アジア及びインド巠大陸の品種と ‘No. 3341’ との $F_{1}$ の生育調査

\begin{tabular}{|c|c|c|c|c|c|c|}
\hline \multicolumn{3}{|c|}{$\begin{array}{c}F_{1} \\
\text { (雑種第一代) }\end{array}$} & $\begin{array}{l}\text { 草たけ } \\
(\mathrm{cm})\end{array}$ & $\begin{array}{l}\text { 本 葉 } \\
\text { 展開数 }{ }^{z}\end{array}$ & $\begin{array}{l}\text { 座止個体 } \\
\text { 発 現率 } \\
(\%)\end{array}$ & $\begin{array}{l}\text { 播種及び } \\
\text { 調 査 }{ }^{y}\end{array}$ \\
\hline 韓国在来 & \multicolumn{2}{|c|}{$\times$ No. 3341} & $22.8 \pm 1.5$ & $13.3 \pm 0.5$ & 0 & 1 \\
\hline 南海在来 & $\times$ & " & $26.1 \pm 2.1$ & $10.7 \pm 0.8$ & 0 & 8 \\
\hline 大邱在来 & $\times$ & " & $2.3 \pm 0.3$ & $2.9 \pm 0.5$ & 100 & 1 \\
\hline 平江在来 & $\times$ & " & $2.2 \pm 0.3$ & $1.9 \pm 0.3$ & 100 & 2 \\
\hline 問鳳在来 & $\times$ & " & $2.0 \pm 0.8$ & $3.0 \pm 1.9$ & 100 & 4 \\
\hline 羊 角 & $\times$ & $"$ & $15.6 \pm 1.4$ & $13.2 \pm 0.9$ & 0 & 1 \\
\hline 台-1 & $\times$ & " & $13.0 \pm 1.0$ & $7.6 \pm 0.3$ & 0 & 9 \\
\hline 中-1 & $\times$ & " & $12.3 \pm 1.7$ & $9.4 \pm 1.2$ & 0 & 7 \\
\hline 石家庄在来 & $\times$ & " & $11.6 \pm 1.8$ & $10.9 \pm 1.5$ & 0 & 6 \\
\hline 燈 籠 & $\times$ & " & $29.3 \pm 2.7$ & $10.8 \pm 1.0$ & 0 & 9 \\
\hline 牛 角 & $x$ & " & $23.8 \pm 3.2$ & $10.6 \pm 1.8$ & 0 & 9 \\
\hline 中-6 & $x$ & " & $26.3 \pm 5.2$ & $9.8 \pm 1.2$ & 0 & 8 \\
\hline 南京早椒 & $x$ & " & $2.9 \pm 0.8$ & $5.5 \pm 11$ & 100 & 5 \\
\hline 中-3 & $x$ & " & $4.0 \pm 0.6$ & $8.3 \pm 1.2$ & 100 & 5 \\
\hline 七寸紅 & $x$ & " & $2.4 \pm 0.4$ & $2.3 \pm 0.6$ & 100 & 6 \\
\hline $\mathrm{CH}-41$ & $x$ & " & $8.2 \pm 1.6$ & $9.1 \pm 1.0$ & 0 & 6 \\
\hline $\mathrm{CH}-42$ & $\times$ & " & $9.2 \pm 1.9$ & $9.7 \pm 2.7$ & 0 & 4 \\
\hline $\mathrm{CH}-19$ & $x$ & " & $20.5 \pm 2.4$ & $8.2 \pm 0.7$ & 0 & 9 \\
\hline $\mathrm{CH}-21$ & $x$ & " & $22.2 \pm 1.5$ & $9.8 \pm 0.8$ & 0 & 9 \\
\hline $\mathrm{CH}-22$ & $x$ & " & $28.4 \pm 1.9$ & $10.8 \pm 1.6$ & 0 & 9 \\
\hline $\mathrm{CH}-28$ & $\times$ & " & $10.0 \pm 1.2$ & $12.0 \pm 0.7$ & 0 & 5 \\
\hline $\mathrm{CH}-30$ & $x$ & $"$ & $6.4 \pm 1.3$ & $9.3 \pm 1.0$ & 0 & 7 \\
\hline TB-12 & $\times$ & " & $18.2 \pm 3.5$ & $8.0 \pm 1.3$ & 0 & 9 \\
\hline TB-13 & $x$ & " & $27.1 \pm 1.2$ & $10.9 \pm 0.7$ & 0 & 9 \\
\hline $\mathrm{CH}-43$ & $\times$ & " & $17.0 \pm 1.0$ & $10.1 \pm 0.5$ & 0 & 8 \\
\hline IS-1 & $\times$ & " & $17.4 \pm 1.7$ & $11.1 \pm 1.3$ & 0 & 8 \\
\hline IS-2 & $x$ & " & $21.3 \pm 4.9$ & $11.6 \pm 1.7$ & 0 & 9 \\
\hline IS-4 & $x$ & " & $23.8 \pm 1.6$ & $8.5 \pm 0.8$ & 0 & 9 \\
\hline IS-5 & $x$ & " & $9.4 \pm 3.0$ & $7.1 \pm 1.6$ & 0 & 8 \\
\hline IS-6 & $\times$ & " & $22.8 \pm 1.0$ & $10.9 \pm 0.7$ & 0 & 8 \\
\hline IS-11 & $x$ & " & $19.6 \pm 2.5$ & $11.5 \pm 1.2$ & 0 & 8 \\
\hline セレベス $\mathrm{No}$ & $1 \times$ & " & $28.1 \pm 1.8$ & $11.5 \pm 0.5$ & 0 & 9 \\
\hline $\mathrm{CH}-4$ & $x$ & " & $20.0 \pm 2.4$ & $13.5 \pm 1.0$ & 0 & 8 \\
\hline
\end{tabular}




\begin{tabular}{|c|c|c|c|c|c|c|}
\hline $\mathrm{CH}-5$ & $x$ & " & $30.4 \pm 1.4$ & $11.7 \pm 0.9$ & 0 & 9 \\
\hline $\mathrm{CH}-7$ & $x$ & " & $31.0 \pm 6.2$ & $13.1 \pm 1.6$ & 0 & 8 \\
\hline $\mathrm{CH}-8$ & $x$ & " & $28.8 \pm 5.8$ & $11.1 \pm 1.9$ & 0 & 8 \\
\hline $\mathrm{CH}-12$ & $\times$ & " & $17.1 \pm 2.4$ & $9.9 \pm 1.5$ & 0 & 3 \\
\hline $\mathrm{CH}-38$ & $x$ & " & $21.6 \pm 2.2$ & 13. $1 \pm 1.0$ & 0 & 2 \\
\hline $\mathrm{CH}-17$ & $x$ & " & $22.1 \pm 1.4$ & $12.8 \pm 1.2$ & 0 & 3 \\
\hline
\end{tabular}

草たけ及び本葉展開数の数值は, $\bar{x} \pm(0.05) \mathrm{SE}$ として表わされている.

$\mathrm{z}, \mathrm{y}$ は第 4 表参照.

認められなかった。

つぎに, アメリカ大陸の品種と 'No. 3341'との $\mathrm{F}_{1}$ の生育調査の結果を第 6 表に示した.

アメリカ合衆国の品種には， ‘No. 3341’ との $F_{1} に$ 座止を発現するものは認められなかった。これらの品種 はベル型大果品種群, ピメント品種群から“カイアン・ ロング・スリム’のような乾果用品種群までを含んでい
た. メキシコ,ボリビア，チリー，アルゼンチンの品種に も座止遺伝子（B）を持つ品種は認められなかった。グ アテマラの 1 品種に座止遺伝子 (B) を持つものが認め られたが，この品種は，芯止り系で我が国の ‘八房”に 類似した品種である。

ヨーロッパの品種については，現在検討中であるが，

第 6 表 アメリカ大陸の品種と ‘No. 3341’ との $F_{1}$ の生育調査

\begin{tabular}{|c|c|c|c|c|c|}
\hline$F_{1}$ (雑種第一代) & & $\begin{array}{l}\text { 草たけ } \\
(\mathrm{cm})\end{array}$ & $\begin{array}{l}\text { 本 葉 } \\
\text { 展開数 }\end{array}$ & $\begin{array}{l}\text { 座止個体 } \\
\text { 発 現 率 } \\
(\%)\end{array}$ & $\begin{array}{l}\text { 播種及び } \\
\text { 調 } \text { 日 }\end{array}$ \\
\hline Hungarian Yellow Wax & $\times$ No. 3341 & $19.9 \pm 1.2$ & $12.7 \pm 0.4$ & 0 & 1 \\
\hline Yolo Wander & $\times \quad \prime$ & $20.3 \pm 1.9$ & $12.0 \pm 1.0$ & 0 & 8 \\
\hline Golden Caluwander & $x$ & $23.5 \pm 1.0$ & $11.7 \pm 0.7$ & 0 & 3 \\
\hline Cayenne Long Slim & $\times$ & $20.0 \pm 3.2$ & $12.8 \pm 1.6$ & 0 & 3 \\
\hline Cayenne Large Red Thick & $x$ & $23.7 \pm 2.4$ & $10.6 \pm 0.8$ & 0 & 8 \\
\hline Cherry Sweet & $x$ & $17.9 \pm 5.9$ & $10.7 \pm 2.7$ & 0 & 3 \\
\hline Red Cherry Small & $x$ & $26.3 \pm 1.8$ & $12.1 \pm 0.9$ & 0 & 8 \\
\hline Red Cherry Large & $x$ & $21.5 \pm 2.1$ & $9.9 \pm 1.0$ & 0 & 8 \\
\hline Fresno Chilli Grande & $x$ & $15.3 \pm 3.9$ & $9.3 \pm 1.7$ & 0 & 8 \\
\hline Anaheim $\mathrm{M}$ & $x$ & $28.8 \pm 1.6$ & $10.7 \pm 0.7$ & 0 & 9 \\
\hline Rumanian Hot & $x$ & $18.2 \pm 3.8$ & $8.1 \pm 1.1$ & 0 & 8 \\
\hline Jalapeño $\mathrm{M}$ & $x$ & $22.3 \pm 1.6$ & $9.7 \pm 0.7$ & 0 & 8 \\
\hline Early Jalapeño & $x$ & $18.5 \pm 1.6$ & $9.0 \pm 0.9$ & 0 & 8 \\
\hline El Paso & $\times$ & $20.8 \pm 15.6$ & $12.5 \pm 6.0$ & 0 & 10 \\
\hline Long Yellow Sweet & $x$ & $19.9 \pm 1.6$ & $11.5 \pm 1.0$ & 0 & 3 \\
\hline Serrano Chilli & $x$ & $18.3 \pm 2.1$ & $9.7 \pm 1.3$ & 0 & 8 \\
\hline Red Chilli & $x$ & $18.2 \pm 1.5$ & $12.3 \pm 1.1$ & 0 & 8 \\
\hline Santa Fe Grande & $x$ & $26.2 \pm 1.9$ & $11.7 \pm 0.8$ & 0 & 9 \\
\hline No. 3251 & $x$ & $22.2 \pm 2.3$ & $12.3 \pm 1.3$ & 0 & 8 \\
\hline No. 3304 & $\times$ & $21.1 \pm 2.8$ & $10.7 \pm 1.2$ & 0 & 8 \\
\hline No. 3446 & $x$ & $8.2 \pm 0.5$ & $11.7 \pm 0.7$ & 0 & 1 \\
\hline No. 3336 & $x$ & $18.4 \pm 1.7$ & $10.1 \pm 1.0$ & 0 & 8 \\
\hline No. 3357 & $x$ & $18.8 \pm 2.3$ & $10.7 \pm 1.2$ & 0 & 8 \\
\hline No. 3412 & $x$ & $5.9 \pm 0.7$ & $6.1 \pm 0.7$ & 100 & 8 \\
\hline No. 3103 & $x$ & $23.2 \pm 3.0$ & $8.5 \pm 0.9$ & 0 & 9 \\
\hline No. 3108 & $x$ & $21.3 \pm 2.6$ & $7.2 \pm 0.8$ & 0 & 9 \\
\hline No. 3028 & $x$ & $15.3 \pm 5.1$ & $10.8 \pm 2.1$ & 0 & 8 \\
\hline
\end{tabular}

草たけ及び本葉展開数の数值は, $\bar{x} \pm(0.05) \mathrm{SE}$ として表わされている.

$\mathrm{z}, \mathrm{y}$ は第 4 表参照. 
スペインの 5 品種, フランスの 4 品種, ベルギーの 4 品 種, ルーマニアの 2 品種の供試品種のいずれにも座止遺 伝子（B）は認められなかった.

以上, 世界各地のトウガラシ品種における座止遺伝子 （B）の有無の結果から, 座止遺伝子（B）を持つ品種 が主に, 我が国, 韓国及び中国の在来品種であることが 明らかとなった。現在, なぜ座止遺伝子を持つ品種が, アジアの一部地域に偏在しているのかは不明である.

トウガラシの我が国への渡来については, 古文書の記 載をもとに, 主として二つの説がある(13).一つは, 貝 原益軒の $1 大$ 和本草」での, “古書に見觉ず。近代の書 に出たり。……昔は日本に之無, 秀吉公朝鮮を伐つ時, 彼国より種子を取来る. 故に俗に高麗胡椒と云……” 説明されている韓国渡来説である. 他の説は, 佐藤信淵 の「草木六部耕種法」にある “蕃椒は最初南亜墨利加州 の東海浜なる伯巠兒国より生じたるものにして, 天文十 一年波两杜瓦爾（ポルトガル）人初めて豊後国に来航し 南瓜の種子と共に国主大友宗鱗に献ぜり”といらポルト ガル人によるトウガラシの渡来説である.

本実験の座止遺伝子 (B) を持つ品種の地理的分布の 結果から, 我が国で古くから栽培されている品種, 韓 国, 中国の在来品種に座止遺伝子 (B) が存在すること が明らかとなった。このことは, 我が国と韓国及び中国 の在来品種との間に遺伝的な共通性があることが認めら れ, 遺伝学的な面から, 我が国へのトウガラシの渡来経 路の一つとして韓国経路の存在の可能性が強く示唆され る.なお,一説には韓国のトウガラシは, 我が国から渡 来したともいわれている(16). いずれにしても, 我が国 と韓国のトウガラシは共通した品種群から分化したもの と思われる。

本実験に供試した品種は，ごく限られたものであり， また品種の選択にも問題が残されている. 今後は, さら 飞多数の品種を供試し実験を行うことが必要である。ま た, C. chinense 'No. 3341' との $\mathrm{F}_{1}$ に座止を発現する 遺伝子を持つ品種が,なぜ原産地から遠く離れた我が国, 韓国及び中国に多く存在するのかは不明である. この点 そついては, C. chinense の 'No. 3341' 以外の品種な らびに南アメリカの C. annuum の品種について,さ らに検討する必要がある.

\section{摘 要}

Capsicum annuum と C. chinense 'No. 3341' と の種問雑種では, 発芽後数節を分化して発育を停止する 座止の発現する場合がある.

座止を発現した個体は，ごくまれな場合を除き，2年 以上栽培し続けても正常に発育することはない。
座止発現個体の根の生育は, 茎葉の生育に比べると良 好で, 正常に生育する品種を穂木として座止個体を接ぎ 木すると根の発育状態は，正常に発育する個体のものに 近かった。

種間交雑に伴 5來止発現には，異なる染色体上にある 2 個の優性補足遺伝子が関与し, 'No. 3341’ はとの中 の 1 個をホモに有することが確められた.

'No. 3341' との交雑で座止を発現するC. annuum の品種は, 我が国で古くから栽培されている品種, 韓国 及び中国の在来品種であった，その他のアジアの品種, インド亜大陸及びアメリカ大陸の品種は, グァテマラの 1 品種を除き，すべて座止遺伝子 ('No. 3341’ の遺伝 子と補足的に作用をする）を持っていなかった。

我が国へのトウガラシの渡来経路については，ポルト ガル人による招来説と韓国渡来説があるが，本実験の結 果から我が国へのトウガラシの渡来経路の一つに韓国経 路が存在したことが遺伝学的に強く示唆された.

謝辞 本実験を遂行するにあたり, 京都大学農学 部田中正武名誉教授, 筑波大学農林学系太田泰雄教授を はじめ多数の方々から貴重な品種の種子を御分譲いただ いた。ここに深甚なる謝意を表する次第である。また， 常に御助力いただいた京都府立大学農学部寺林 敏助手 に謹しんで感謝する。

\section{引用文献}

1. 雨宮 昭・明峰英夫. 1963. イネの致死補足遺伝 子に関专る遗伝生化学的研究（イネの胚培養に関 寸る研究 3 ). 農技研報告D. $10: 139-226$.

2. ANDrews, J. 1984. Peppers. p. 1-10. Univ. Texas Press. Austin.

3. BRantley, B. B. 1983. A genetic abnormality causing virus-like symptoms and sterility in cowpea. HortScience 18: 458-459.

4. Cook, A. A. 1961. Inheritance of mutant-1 phenotype in the pepper. J. Hered. 52:154158.

5. Coyne, D. P. 1965. A genetic study of 'crippled' morphology resembling virus symptoms in Phaseolus vulgaris L., J. Hered. $56: 162-176$.

6. Egawa, Y. and M. TanakA. 1984. Cytogenetical relationships among three species of chilli peppers, Capsicum chinense, C. frutescens and C. bacctum. Japan. J. Breed. 34: 50-56.

7. Egawa, Y. and M. Tanaka. 1984. Structural differentiation of chromosomes by reciprocal translocation in Capsicum annuum. Japan. J. Breed. 34 : 445-450.

8. Egawa, Y. and M. TanakA. 1986. Cyto- 
genetical study of the interspecific hybrid between Capsicum annuum and C. baccatum. Japan. J. Breed. 36: 16-21.

9. Eshbaugh, W. H. 1970. A biosystematic and evolutionary study of Capsicum baccatum (Solanaceae) Britonia 22: 31-43.

10. Hermsen, J. G. TH. 1957. Semi-lethal in hybrid of offspring of wheat. Euphytica 6: 18-25.

11. HEDRICK, U.P. (ed.) 1919. Sturtevant's notes on edible plant. p. 134-140. J. B. Lyon Comp., State Printers, Albany.

12. 広瀬忠彦・西 新也・高嶋四郎. 1960 . トウガラ シ属栽培種の種間交雑に関する研究 I 。種間の交 雑可能度について。京都府大学報・農. 12:4046.

13. 木原 均・盛永俊太郎・篠遠喜人・筑波常治 - 内 田亭・上野益三. 1973. 黎明期日本の生物史 p. 112-113. 養賢堂. 東京.

14. 熊沢三郎 - 小原 赴 -二井内清之. 1954. 本邦に おけるとうがらしの品種分化. 園学雑. 23 : 152158.

15. Lippert, L. F., B. O. Bergh and A. A. CoOK. 1964. Three variegated seedling mutants in the pepper. Multiple allelism indicated in crossing studies. J. Hered. $56: 79-83$.

16. 大野史朗. 1982. 農業事物起源集成 (第 2 刷) p. 283-284. 青史社. 東京.

17. 太田泰雄. 1962. トウガラシ属の核型. 生研時報. $13: 93-99$.

18. OKA, H. 1957. Phylogenetic differentiation of cultivatnd rice. XV. Complementary lethal genes in rice. Japan. J. Genet. 32: 83-87.

19. Pickersgill, B. 1977. Choromosomes and evolution in Capsicum. Capsicum 77: 27-37.

20. Singh, S. and J. A. Gutierrez. 1984. Geographical distribution of the DL, and DL genes causing hybrid dwarfish in Phaseolus vulgaris L., their association with seed size, and their significance to breeding. Euphytica $33: 337-345$.

21. 高橋隆平・林 二郎・守屋 勇. 1971. 補足遺伝 子による大麦雑種の幼苗致死の研究. I . その遺 伝様式と関与遺伝子の地理的分布. 農学研究. 53 : 197-204.

22. TANAKA, M. 1965. phylogenetic relationship and species differentiation in genus Triticum with special reference to the genotypes for dwarfness. Mem. Coll. Agri. Kyoto Univ. 87: 1-30.
23. 冨久保男・高橋隆平. 1971. 補足遺伝子による大 麦雑種の幼苗致死の研究. II. 幼苗の形態解剖学 的研究. 農学研究. $54: 15-22$.

24. 常脇恒一郎. 1960. 普通小麦におけるモノソミッ クおよび簡便遺伝子分析. III. 致死性. 遺伝雑. $35: 71-75$.

25. Tsunewaki, K. and T. Hori. 1967. Distribution of necrosis genes in wheat. IV. Common wheat from Australia, Tibet and Northern Europe. Japan. J. Genet. 42: 245-250.

26. TsunewaKI, K., F. KASAhara and $T$. FUJITA. 1971. Distribution of necrosis genes in wheat. VI. Chinese common wheat. Japan. J. Genet. 46 : 103-107.

27. TSUNEWAKI, K. and Y. NAKAI. 1961. Distribution of necrosis genes in wheat. I. Common wheat from Central Asia. Can. J. Genet. Cytol. 9: 69-74.

28. TSUnEWAKI, K. and Y. NAKAI. 1967. Distribution of necrosis genes in wheat. II. Japanese local varieties of common wheat. Can. J. Genet. Cytol. 9: 75-78.

29. TSUnEWAKI, K. and Y. NAKAI. 1967. Distribution of necrosis genes in wheat. III. U. S. Common wheat. Can. J. Genet. Cytol. 9: 385393.

30. YAmAMOTO, Y. 1978. The origin and domestication of Capsicum peppers. Thesis, Kyoto Univ.

31. 矢澤 進・松永隆志・高嶋四郎. 1978. 野生卜ウ ガラシの栽培利用に関する研究. (第 1 報) 野生 トウガラシ No. 3341 と栽培品種間の一代雑種の 特性. 園学要旨. 昭 53 春 : 194-195.

32. 矢澤 進・佐藤隆德・並木隆和. 1981. キレート 鉄による生育障害.（第 1 報）トウガラシにおけ る $\mathrm{NaFe}$ EDTA の生育障害. 園学要旨。昭 56 秋: 242-243.

33. 矢澤 進・佐藤隆徳・並木隆和. 1981. キレート 鉄による生育障害.（第 2 報）キレート鉄の生育 障害の回避について。園学要旨. 昭 56 秋 : 244245.

34. 矢澤 進・佐藤隆徳・並木隆和. 1982. キレート 鉄による生育障害（第 3 報）トウガラシの茎葉内 鉄濃度と生育障害. 園学要旨. 昭 57 秋 : 244-245.

35. WHITAKER, T. W. 1964. Virus-like syndromes of Cucurbita speies hybrids. Heredity 19: 229236.

36. ZEVEN, A.C. 1966. Geographical distribution of genes causing hybrid necrosis in wheat. Euphytica 15: 281-284. 